\title{
Analysis for sizing of the stand-alone solar photovoltaic thermal system for the residential house at Sultanpur
}

Shweta Singh ( $\nabla$ shwetaknit.ec@gmail.com )

Kamla Nehru Institute of Technology https://orcid.org/0000-0002-1855-5341

Rakesh Kumar Singh

KNITSultanpur

Gopal Nath Tiwari

Bag Energy Reseach Society (BARS)

Original article

Keywords: Solar radiation, photovoltaic thermal system, performance evaluation, energy analysis, economical analysis

Posted Date: July 23rd, 2020

DOI: https://doi.org/10.21203/rs.3.rs-34112/v1

License: (c) (i) This work is licensed under a Creative Commons Attribution 4.0 International License. Read Full License 


\section{Abstract}

Background: In this article, the potential applications of the solar photovoltaic thermal system have been discussed. The increasing cost and rapid depletion of conventional energy, researchers are optimizing the use of solar energy in residential and commercial purposes-the scope of solar energy, providing an alternative for residential and commercial power requirements. The average power requirement of a residential house is calculated with the help of power ratings. Hourly, daily, and monthly power requirement is calculated for designing the optimum size of solar photo voltaic thermal.

Results: A stand-alone solar photovoltaic thermal system has been designed. For the sizing of the solar photovoltaic thermal system, meteorological data are collected through Synergy Enviro and PVWatts Calculator. The mathematical calculation and simulation study has been performed to estimate the expected power generation from the PVT. The cash flow and payback period of PVT are calculated. The total cost of installation was rupees 114450/- and the payback period was 9 years approximately.

Conclusions: The forecasted output of solar photovoltaic thermal has been calculated based on solar radiation value obtained from different sources. The significant finding of the present study are: The maximum and the minimum electrical load was approximately $7.7 \mathrm{kWh}$ per day in summer and about 2.5 $\mathrm{kWh}$ per day in winter. The maximum and minimum solar radiation at the installed site was $7.08 \mathrm{kWh} / \mathrm{m}$ 2 / day and $3.32 \mathrm{kWh} / \mathrm{m} 2$ / day. The maximum electrical power calculated by installed solar module is $2466 \mathrm{kWh}$ per year.

\section{Introduction}

The demand for energy is increasing exponentially in developing countries due to enhanced living standard and economic development. The cost of fossil fuels based electricity is also growing and leaving massive $\mathrm{CO}_{2}$ emission in the environment. Now there is an enormous impact of renewable energy to overcome these issues. The solar photovoltaic (P.V.) has been proved to be the most efficient and robust way to harness electrical energy from solar radiations. The cell temperature of the solar photovoltaic panel increases with an increase in solar radiation and environment temperature. The efficiency of P.V. decreases with increase in cell temperature. Thermal energy is extracted from the solar P.V. panel, and solar photovoltaic thermal (PVT) systems are used instead of solar P.V. to overcome this issue.

There is numerous configuration of photovoltaic systems; the essential configurations are grid-connected P.V. system and stand-alone photovoltaic system [1]. The consumption of fossil fuel and the emission of greenhouse gases can be drastic decreases by using photovoltaic thermal (PVT) hybrid technology [2]. Kalogirou and tripanagnostopoulos [3] reported that a large portion of solar radiation converted into thermal energy, increasing solar cell temperature. The efficiency of mono-crystalline and polycrystalline silicon solar cells decreases by about $0.45 \%$ / for the rise in cell temperature above 25 . Ji et al.[4] reported that more than $80 \%$ of the solar radiation falling on photovoltaic cells is not converted into electricity and 
most of this energy converted thermal energy, the process of extraction of heat from solar P.V. to increase cell efficiency is called hybrid PVT.

For generating electrical power and hot water, many configurations of photovoltaic flat plate collectors have been designed and developed by several researchers [5]-[7]. Dubey and Tiwari [8] analyzed overall annual energy and exergy generated in the form of heat and electricity from a hybrid PVT at five different climatic conditions. Kumar and Rosen [9] determined the thermal performance of an integrated solar water heater (PVT) with a corrugated absorber surface, rectangular collector/storage heat transfer rate between the absorber surface and the water, and on the amount of solar radiation incident on the absorber surface. Tiwari et al. [10] have presented an analytical expression of an integrated photovoltaic thermal solar (IPVTS) for the constant water temperature under continuous flow rate. The overall exergy and thermal efficiency analysis of an integrated photovoltaic thermal solar are also carried out. Joshi and Tiwari [11] evaluated exergy analysis of a hybrid PVT parallel plate air collector for the cold climatic condition of India (Srinagar). They also observed and compared instantaneous energy and exergy efficiency of a PV/T air heater with other researchers' data. The electrical efficiency of different P.V. systems is different, which depends on technology and material used. The performance of the solar P.V. system depends strongly on meteorological condition such as solar radiation, wind velocity and temperature [12]. The P.V. system must be correctly dimensioned to supply uninterrupted solar energy during the year. This requires a rigour study to optimize the size and feasibility of solar PVT for the most efficient and leat investment [13].

The various performance parameters, including energy yield, wind velocity ambient temperature and performance ratio, are used to characterize the P.V. system [14]. Several studies have been done on the performance evaluation of P.V. system. Khatib et al. [15] carried a review for size optimization on P.V. system for stand-alone and in combination with other systems as a hybrid. They concluded that the optimization of P.V. system firmly depends on meteorological variables. So it is necessary to have a detailed analysis of location for accurate output of solar P.V. An increase in output of P.V. system energy will reduce the size of P.V. array and the capital cost of investment [16]. Arab et al. [17]discussed a method for estimating the loss-of-load probability (LLP) of a photovoltaic water pumping system to evaluate the optimum P.V. array configurations. The LLP was defined as the ratio between the number of hours of the water deficit and the number of hours of consumption [18]. Some researchers at sultanpur climatic condition have performed experimental work on PVT, and they found that there is an improvement in P.V. efficiency by extracting heat from the module by using oscillatory tube and phase changing materials [19], [20]

Thus it is obvious that the flat plate PVT solar collector is a useful energy conversion system for residential application which requires electrical power and thermal energy both. This study is focussed on the sizing of solar PVT for the middle class family with an average demand of electricity and hot water. In the present study, the actual requirement of electrical energy is calculated based on power rating and its usage hours. Based on the availability of meteorological data of monthly solar radiation 
predicted/forecasted at the position where solar PVT has to install. The electrical energy and thermal energy produced per unit area can be predicted based on forecasted solar radiation value.

A system consisting of a PVT panel, a battery system and thermal storage is used to fulfil the household requirements. An illustrative example is used to demonstrate the power and thermal need. Several constraints imposed on a PVT system to optimize the design space. The prediction of all feasible output, the economic optimization and payback period of the system is studied.

\section{Methodology}

The residential houses required both thermal and electrical energy. The actual energy requirement is computed daily and monthly basis. The maximum energy required by the residential home was selected for designing the optimum size of P.V. module. The power produced by the module is used in the day time, and excess energy is stored in the battery. The important input of the P.V. module is meteorological data which include solar radiation, atmospheric temperature, wind velocity, and cell temperature. The following steps are used in sizing the PVT system for a household in this study.

Steps 1. Calculations of the hourly electrical power consumption for the summer season.

Steps 2. Calculations of the hourly electrical power consumption for the winter season.

Steps 3. Calculations of the monthly electrical power consumption throughout the year.

Steps 4. Based on the above, 3 point estimate required output from P.V. module.

Steps 5. Select the location of installation of P.V. and estimate solar radiation

Steps 6. Based on available solar radiation, module efficiency and required P.V. output decide the size of P.V. module.

Above steps decide the actual size of P.V. module but thermal energy produce through PVT will be sufficient for household usage. Therefore no sizing rule is required for thermal energy need. The energy balance for the PVT system is represented by the following equations. 


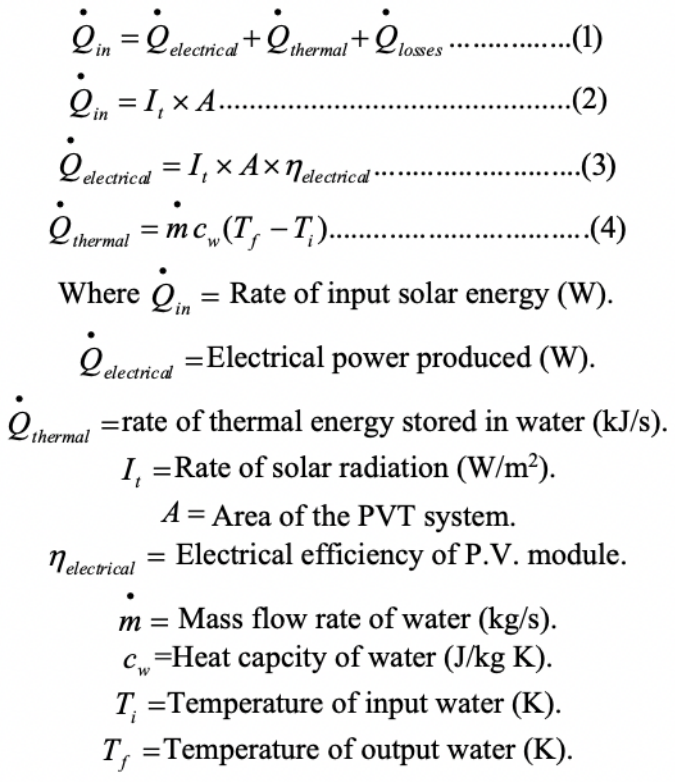

Where $Q_{\text {in }}=$ Rate of input solar energy (W)

$\dot{Q}_{\text {electrical }}=$ Electrical power produced (W).

$\dot{Q}_{\text {thermal }}=$ rate of thermal energy stored in water $(\mathrm{kJ} / \mathrm{s})$.

$I_{t}=$ Rate of solar radiation $\left(\mathrm{W} / \mathrm{m}^{2}\right)$.

$A=$ Area of the PVT system.

$\eta_{\text {electrical }}=$ Electrical efficiency of P.V. module.

$\dot{m}=$ Mass flow rate of water $(\mathrm{kg} / \mathrm{s})$.

$c_{w}=$ Heat capcity of water $(\mathrm{J} / \mathrm{kg} \mathrm{K})$.

$T_{i}=$ Temperature of input water $(\mathrm{K})$.

$T_{f}=$ Temperature of output water $(\mathrm{K})$.

\subsection{Site details and average solar radiation}

The residential house of KNIT Sultanpur (U.P.) India is selected for the current study. It is located at the latitude of $26.2888^{\circ} \mathrm{N}$, the longitude of $82.0823^{\circ} \mathrm{E}$. The KNIT Sultanpur get electrical power from Uttar Pradesh Power Corporation Ltd. (UPPCL) at the commercial rate which also shared by residential houses. The cost of electricity per unit is Rs. 10 per unit. The rooftop of the residential house is selected for standalone installation. The average annual temperature of the site is 25 . The average sun global radiation is $1773 \mathrm{kWh} / \mathrm{m}^{2}$ to $1837 \mathrm{kWh} / \mathrm{m}^{2}$. The solar radiation data can be estimated by many open-access software and web-based application. The important software to access solar radiation data is $\mathrm{PV} \star \mathrm{SOL}$, SolarGIS, PVGIS, SISIFO, PVsyst[21], MNRE, SYNERGY ENVIRO PVwatts calculator.

\subsection{System description}

The solar photovoltaic thermal system must design in such manner that, it extracts the maximum amount of thermal energy through circulating water behind the panel. The PVT system should be installed on the rooftop of the residential house. The schematic diagram of the residential house with installed PVT system along with different load are represented in Figure 1.

\subsection{Load estimation}

The residential house selected for current study having four-room one lobby one kitchen and two bathrooms, and constructed in approximately $150 \mathrm{~m}^{2}$ area. The actual equipment installed in the house, with their power rating is given in table 1 . The actual operating hour of the different types of equipment are different, and it is presented in table 2 and table 3 for summer and winter, respectively. The hour 1 means duration between 00:00 HRS to 1:00 HRS and hour 24 means duration between 23:00 HRS to 24:00 HRS. The hourly load distribution presented in table 2 and table 3 is actually based on observation recorded by the author. 
Table 1: Equipment with number of unit and power rating

\begin{tabular}{ccc}
\hline S. N.Device/EquipmentNo of unitPower rating $(W)$ \\
\hline LED (Lamp) & 9 & 7 \\
TV & 1 & 28 \\
PC & 1 & 65 \\
Mobile & 1 & 18 \\
Fan & 5 & 80 \\
Refrigerator & 1 & 35 \\
Washing M/C & 1 & 500 \\
Desert Cooler & 2 & 200 \\
\hline
\end{tabular}

Table 2: Hourly Load distribution in summer per equipment per hour

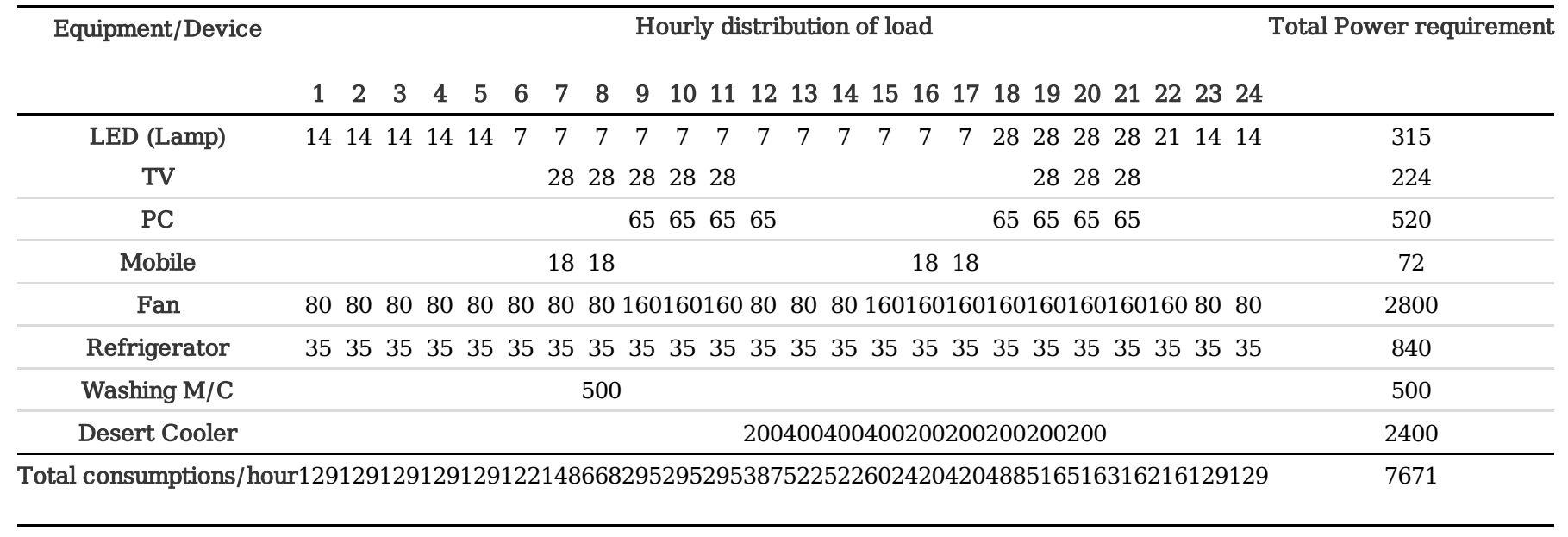

Table 3: Hourly Load distribution in winter per equipment per hour

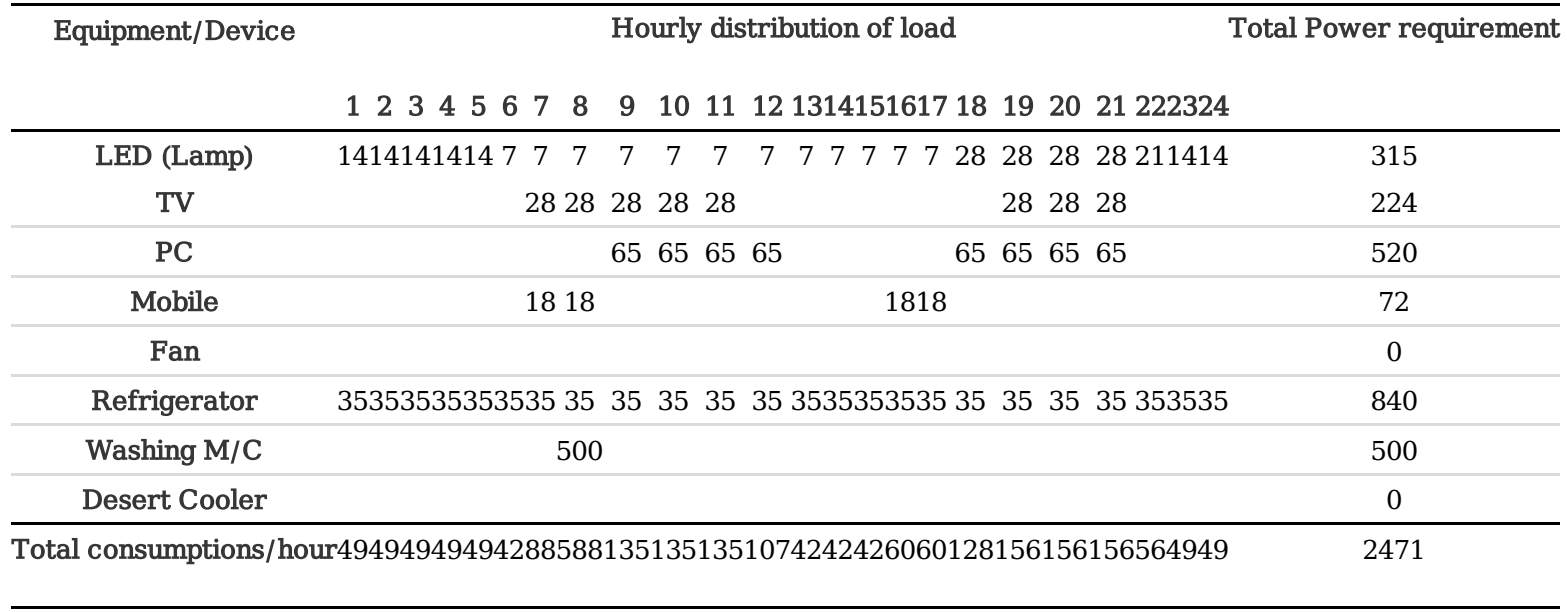

\subsection{Sizing of a PVT system}

The optimum size of PVT depend on the electrical and thermal energy requirement, but it also depends on types of solar panel, technology, solar radiation, ambient condition orientation of the panel. The 
maximum electrical power requirement is approximately $7700 \mathrm{Wh}$ with an average clear sky of $8 \mathrm{hrs}$ per day in summer. The minimum electrical power requirement is approximately $2500 \mathrm{Wh}$ with an average clear sky of 5 hrs per day in winter. Therefore, the electrical capacity of the P.V. module can be calculated as

The average required electrical power production /hour from P.V. module in the summer season

$=7700 / 8=962.5$ Wh (for 8 hours)

The average required electrical power production /hour from P.V. module in the winter season

$=2500 / 5=500 \mathrm{Wh}$ (for 5 hours)

The power rating of P.V. module for fulfilling the average power requirement in both summer and winter condition should be $962.5 \mathrm{Wh}$. On considering a safety factor of 1.25 , the approximate power rating of required P.V. module will be $1.2 \mathrm{kWh}$. Therefore, four modules of $300 \mathrm{~W}$ or three modules of $400 \mathrm{~W}$ is required to fulfil the electrical demand of the domestic house. The thermal attachment incorporated in P.V. module will provide a sufficient amount of hot water for domestic use. So there is no need to think about the sizing of PVT on the ground of thermal energy. The module area of installed P.V. for producing $1.2 \mathrm{kWh}$ was $7.77 \mathrm{~m}^{2}$.

\subsection{Cost estimation}

The production of solar energy is determined by calculating the different cost of materials, and their installation has been determined. The different materials of solar PVT are P.V. module, Battery, Charge controller, inverter, dump load, thermal attachment and hot water storage tank with all connection. The installation cost of the PVT has been calculated and presented in table 4. The cost PVT mentioned in table 4 is a one-time investment for getting power up to 25 years (i.e. the life of P.V. module).

Table 4: Cost of materials/parts

\begin{tabular}{ccc}
\hline S.N. & Materials/parts & Approximate cost (INR) \\
\hline & Solar Panel & 38400 \\
Battery & 45000 \\
Inverter & 15000 \\
Charge Controller & 1050 \\
Thermal Attachment & 5000 \\
Miscellaneous expenses & 10000 \\
\hline Total & 114450 \\
\hline
\end{tabular}

\section{Results And Discussion}

The electrical power requirement and solar radiation is the most crucial factor for determining the size of P.V. module. The hourly variations of electrical load in summer and winter season are presented in figure 
2 and figure 3. All the installed equipment are operated as per the requirement of the person residing in the house. In case excess or shortage management of P.V. power produce, a dump load (by running extra equipment) or switching off some equipment may solve the problem. The average power requirement $(\mathrm{Wh})$ per day in a different month of the year are recorded and presented in figure 4.

The performance of P.V. module depends on solar radiation and a number of clear sky hour/ day, but the solar radiation depends on site-specific meteorological data. The solar radiation data of any site can be obtained from various software and web-based application by entering the latitude, longitude and altitude. The solar radiation data of the installed site is obtained by Synergy Enviro and NREL's PVWatts Calculator. The average solar radiation per day obtained by Synergy Enviro in different months of the year is presented in figure 5, while data collected by NREL's PVWatts Calculator is presented in figure 6.

The output of the P.V. panel depends on the intensity of solar radiation and the area of the module. The average radiation in winter is less as compared to summer. Therefore the same module produces more electricity in summer than winter condition. The reason behind it is the average time of radiation and clearness of the sky. In winter, because the tilt of the earth causes the sunlight to be spread over a larger area, this is the second reason for low radiation on the earth surface in the winter season. The module with $1.2 \mathrm{~kW}$ capacities with input solar radiation as per figure 5 and figure 6 , produce electrical power output as presented in figure 7 and figure 8 . The following formula calculates the expected electrical power output:

Expected electrical power output $=$ Solar radiation $\left(\mathrm{kW} / \mathrm{m}^{2}\right) \times$ module area $\times$ Efficiency of P.V.

The area of P.V. module $=7.77 \mathrm{~m}^{2}$ and efficiency of the P.V. module $=0.16$.

Figure 9 shows the monthly consumption of electrical power, which is received from installed PVT at the desired domestic house. Monthly power consumption presented in figure 9 is lower than the average forecasted value of the power produced in figure 7 and figure 8. It means in general no shortage of power from an installed capacity of P.V. module. If only P.V. panel is used without attaching thermal system behind it, then the addition $15 \mathrm{kWh}$ per month is required for getting hot water. Therefore, the monthly power requirement from the grid will be $15 \mathrm{kWh}$ higher than the average requirement presented in figure 9 . The average power consumption per month from the grid is shown in figure 10. The monthly saving of electrical power cost is calculated by multiplying energy cost per kWh with monthly consumption of energy in kWh without stand-alone PVT. The approximate saving is presented in table 5 by considering the cost of grid electricity @10 rupees/ kWh.

Table 5: Monthly saving by using PVT system

Month Jan Feb Mar Apr May Jun July Aug Sep Oct Nov Dec Total

Saving (INR)891.3891.31126.51366.52445.32445.31966.51966.51366.51126.5891.3891.316483.5 
The total investment of the PVT system for installing it on the residential house with load mentioned above is Rs. 114450/-. The yearly saving has been calculated as Rs. 16483.5/-. Therefore the simple payback period is calculated by dividing total investment with annual saving. The simple payback period is approximately seven years, with the above-mentioned load, cost of installation and price of electricity. If the investment is supported by any financial institutions at a $10 \%$ rate of interest, then the payback period will be approximately nine years. The cash flow of the PVT system for an average life of 25 is represented in figure 11 by assuming that financial institutions support investments and return both at $10 \%$ rate of interest.

\section{Conclusions}

The mathematical calculation and simulation study was carried out to determine the load requirement and available solar radiation per unit area. The forecasted output calculated based on solar radiation value obtained from different sources. The required capacity of the installed P.V. module was $1.2 \mathrm{~kW}$ for fulfilling the power requirement of the residential house. The significant finding of the present study are:

1. The maximum and minimum electrical load was approximately $7.7 \mathrm{kWh}$ per day in summer and about $2.5 \mathrm{kWh}$ per day in winter.

2. The maximum and minimum solar radiation at the installed site was $7.08 \mathrm{kWh} / \mathrm{m}^{2} /$ day and 32 $\mathrm{kWh} / \mathrm{m}^{2} /$ day.

3. The maximum electrical power calculated by installed solar module is $2466 \mathrm{kWh}$ per year.

4. The average requirement of electrical power was $1737.5 \mathrm{kWh} /$ year.

5. The simple payback period of the PVT system was approximately seven years and in case of financially supported by any institutions at the interest of $10 \%$ then the payback period will be nearly nine years.

6. The initial cash flow was Rs 114450 in the negative side at the start of the project, and the final cash flow at the end of 25 years was Rs 3,99,141 positive side.

\section{Declarations}

Ethical Approval and Consent to participate: This study is performed for analyzing the requirement of optimum PV size for a household, and all the data of this research is ready to share any researchers word wide.

Consent for publication: All the authors of the manuscript are agreed to publish this article without any reservation.

Availability of supporting data: All the data related to this article are collected by the corresponding author and can be accessed by any person on request.

Competing interests: The authors declare that they have no competing interests. 
Funding: There is no funding available for current research work.

Authors' contributions: The first author has carried out all the research work, and reaming co-authors have advised and added valuable input in the preparation of the manuscripts.

Acknowledgments: The authors would like to thank Coordinator TEQIP-III for Providing a financial assistantship to continue this research work.

\section{References}

[1] M. E. Menconi, S. dell'Anna, A. Scarlato, and D. Grohmann, "Energy sovereignty in Italian inner areas: Off-grid renewable solutions for isolated systems and rural buildings," Renew. Energy, vol. 93, pp. 14-26, 2016, doi: 10.1016/j.renene.2016.02.034.

[2] X. Zhang, X. Zhao, S. Smith, J. Xu, and X. Yu, "Review of R\&D progress and practical application of the solar photovoltaic/thermal (PV/T) technologies," Renew. Sustain. Energy Rev., vol. 16, no. 1, pp. 599-617, 2012, doi: 10.1016/j.rser.2011.08.026.

[3] S. A. Kalogirou and Y. Tripanagnostopoulos, "Hybrid PV/T solar systems for domestic hot water and electricity production," Energy Convers. Manag., vol. 47, no. 18-19, pp. 3368-3382, 2006, doi: 10.1016/j.enconman.2006.01.012.

[4] J. Ji, J. P. Lu, T. T. Chow, W. He, and G. Pei, "A sensitivity study of a hybrid photovoltaic/thermal waterheating system with natural circulation," Appl. Energy, vol. 84, no. 2, pp. 222-237, 2007, doi: 10.1016/j.apenergy.2006.04.009.

[5] H. A. Zondag, "Flat-plate PV-Thermal collectors and systems: A review," Renew. Sustain. Energy Rev., vol. 12, no. 4, pp. 891-959, 2008, doi: 10.1016/j.rser.2005.12.012.

[6] T. T. Chow, "A review on photovoltaic/thermal hybrid solar technology," Appl. Energy, vol. 87, no. 2, pp. 365-379, 2010, doi: 10.1016/j.apenergy.2009.06.037.

[7] A. Ibrahim, M. Y. Othman, M. H. Ruslan, S. Mat, and K. Sopian, "Recent advances in flat plate photovoltaic/thermal (PV/T) solar collectors," Renew. Sustain. Energy Rev., vol. 15, no. 1, pp. 352-365, 2011, doi: 10.1016/j.rser.2010.09.024.

[8] S. Dubey and G. N. Tiwari, "Energy and exergy analysis of hybrid photovoltaic/thermal solar water heater considering with and without withdrawal from tank," J. Renew. Sustain. Energy, vol. 2, no. 4, 2010, doi: 10.1063/1.3464754.

[9] R. Kumar and M. A. Rosen, "A critical review of photovoltaic-thermal solar collectors for air heating," Appl. Energy, vol. 88, no. 11, pp. 3603-3614, 2011, doi: 10.1016/j.apenergy.2011.04.044. 
[10] A. Tiwari, S. Dubey, G. S. Sandhu, M. S. Sodha, and S. I. Anwar, "Exergy analysis of integrated photovoltaic thermal solar water heater under constant flow rate and constant collection temperature modes," Appl. Energy, vol. 86, no. 12, pp. 2592-2597, 2009, doi: 10.1016/j.apenergy.2009.04.004.

[11] A. S. Joshi and A. Tiwari, "Energy and exergy efficiencies of a hybrid photovoltaic-thermal (PV/T) air collector," Renew. Energy, vol. 32, no. 13, pp. 2223-2241, 2007, doi: 10.1016/j.renene.2006.11.013.

[12] A. K. Shukla, K. Sudhakar, and P. Baredar, "Exergetic assessment of BIPV module using parametric and photonic energy methods: A review," Energy Build., vol. 119, pp. 62-73, 2016, doi: 10.1016/j.enbuild.2016.03.022.

[13] M. Missoum, A. Hamidat, K. Imessad, S. Bensalem, and A. Khoudja, "Impact of a grid-connected P.V. system application in a bioclimatic house toward the zero energy status in the north of Algeria," Energy Build., vol. 128, pp. 370-383, 2016, doi: 10.1016/j.enbuild.2016.07.005.

[14] A. K. Shukla, K. Sudhakar, and P. Baredar, "Design, simulation and economic analysis of stand-alone roof top solar P.V. system in India," Sol. Energy, vol. 136, pp. 437-449, 2016, doi: 10.1016/j.solener.2016.07.009.

[15] T. Khatib, A. Mohamed, and K. Sopian, "A review of photovoltaic systems size optimization techniques," Renew. Sustain. Energy Rev., vol. 22, pp. 454-465, 2013, doi: 10.1016/j.rser.2013.02.023.

[16] D. Langridge, W. Lawrancedagger, and B. Wichert, Development of a photovoltaic pumping system using a brushless d.c. motor and helical rotor pump," Sol. Energy, vol. 56, no. 2, pp. 151-160, 1996, doi: 10.1016/0038-092X(95)00077-5.

[17] A. Hadj Arab, F. Chenlo, and M. Benghanem, "Loss-of-load probability of photovoltaic water pumping systems," Sol. Energy, vol. 76, no. 6, pp. 713-723, 2004, doi: 10.1016/j.solener.2004.01.006.

[18] Eduardo Lorenzo, Solar electricity: engineering of photovoltaic systems. PROGENSA, 1994.

[19] R. Singh, A. Kumar, and A. Yadav, "Performance analysis of solar photovoltaic thermal system using phase change materials," in International conference on advances in materials and manufacturing applications, 2018.

[20] S. Singh, R. K. Singh, and G. N. Tiwari, "Effect of Oscillatory Water Flow on the Performance of Photovoltaic Thermal System in Summer Condition," in 2018 International Conference on Computational and Characterization Techniques in Engineering \& Sciences (CCTES), 2018, pp. 221-226, doi: 10.1109/CCTES.2018.8674075.

[21] C. Dondariya et al., "Performance simulation of grid-connected rooftop solar P.V. system for small households: A case study of Ujjain, India," Energy Reports, vol. 4, pp. 546-553, 2018, doi:

10.1016/j.egyr.2018.08.002. 
Figures
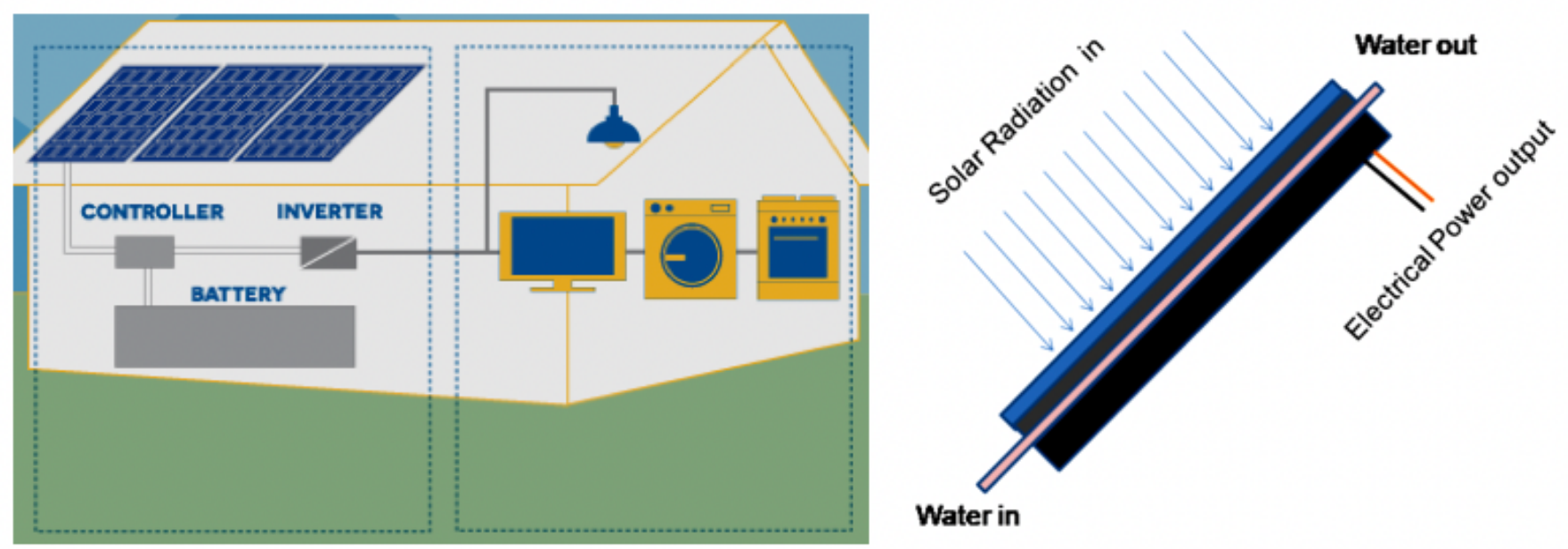

Figure 1

Schematic diagram of typical home with standalone PVT

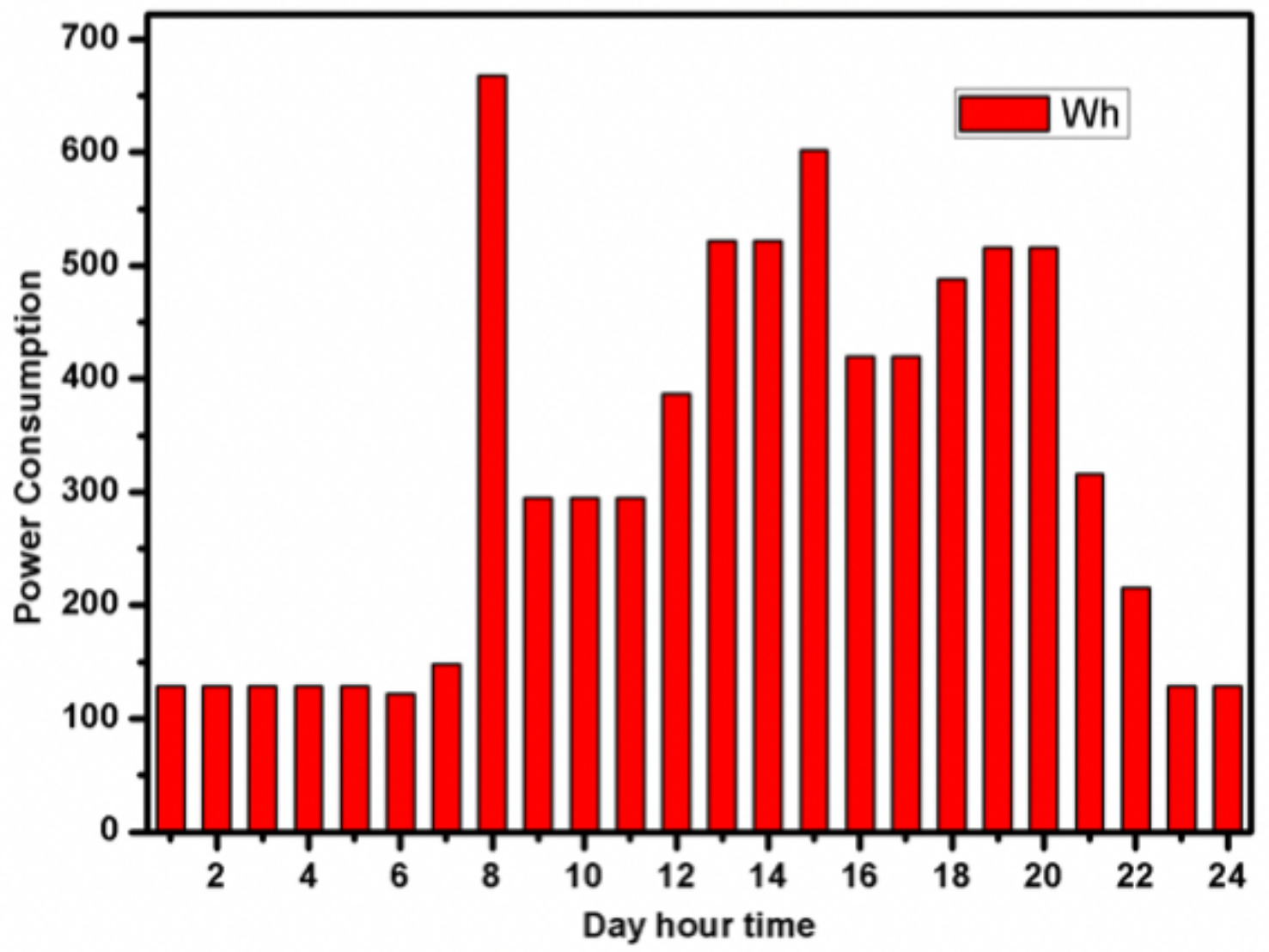

Figure 2 
Hourly power consumption in summer

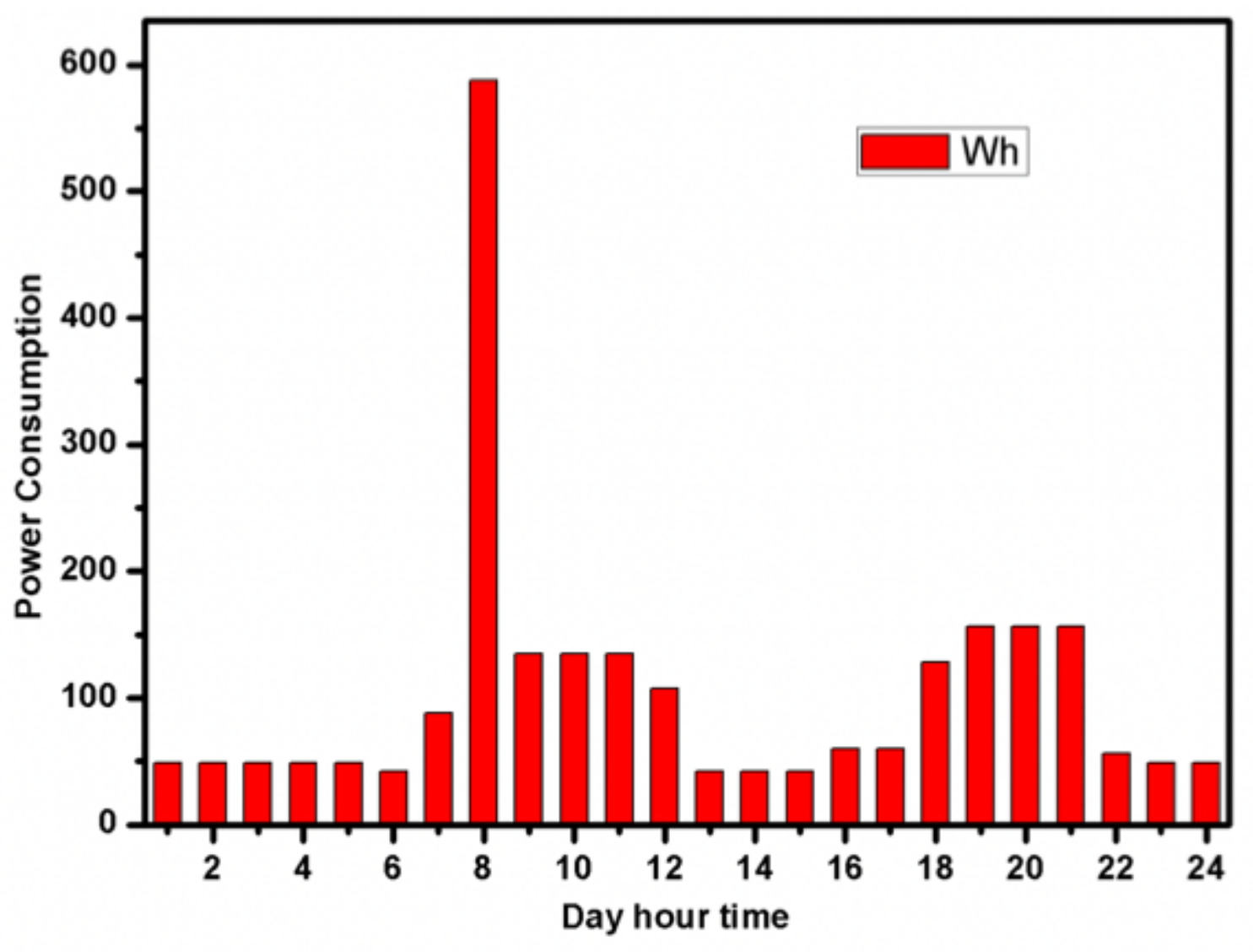

Figure 3

Hourly power consumption in winter 


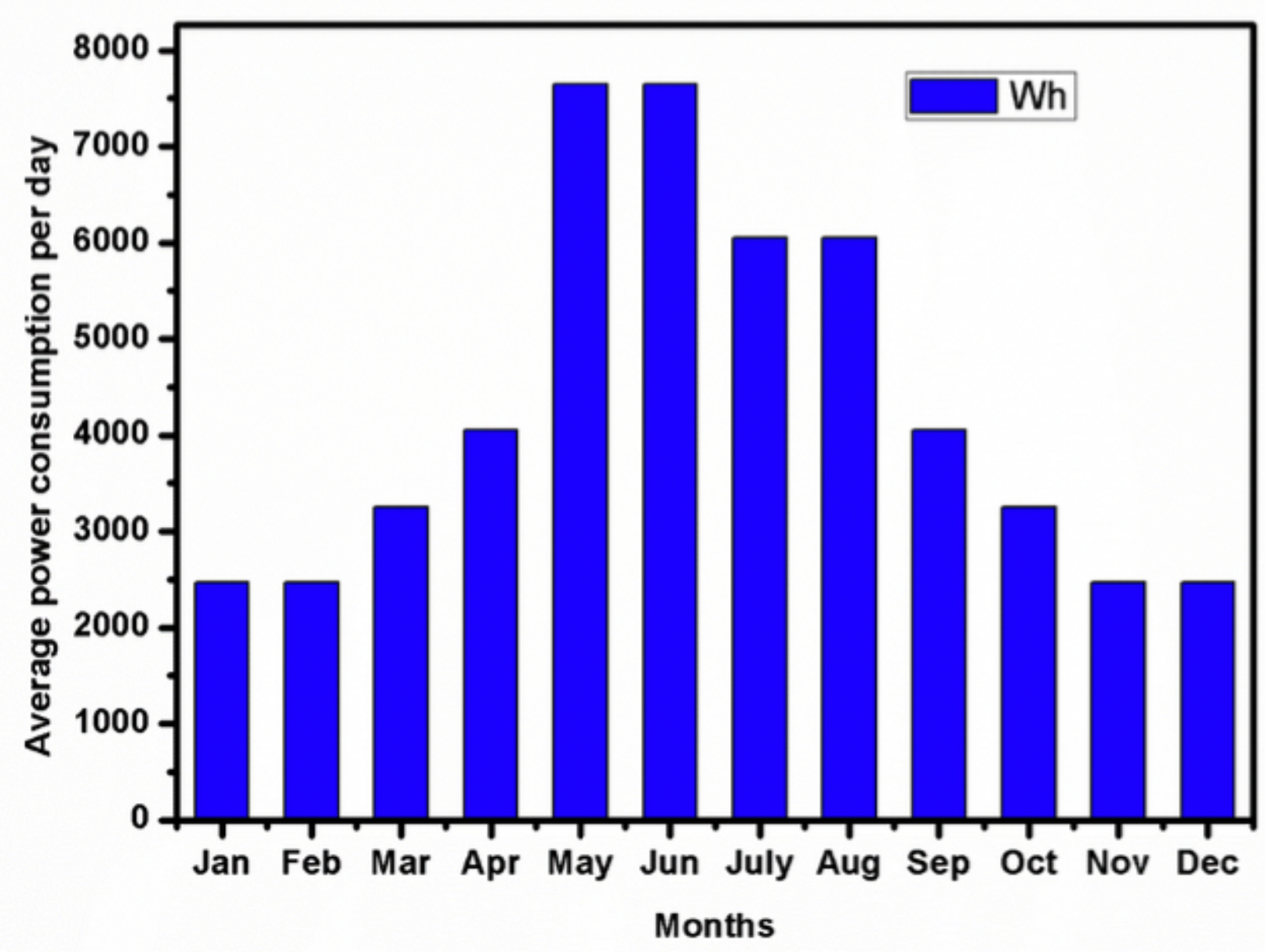

Figure 4

Average power consumption per day in different month 


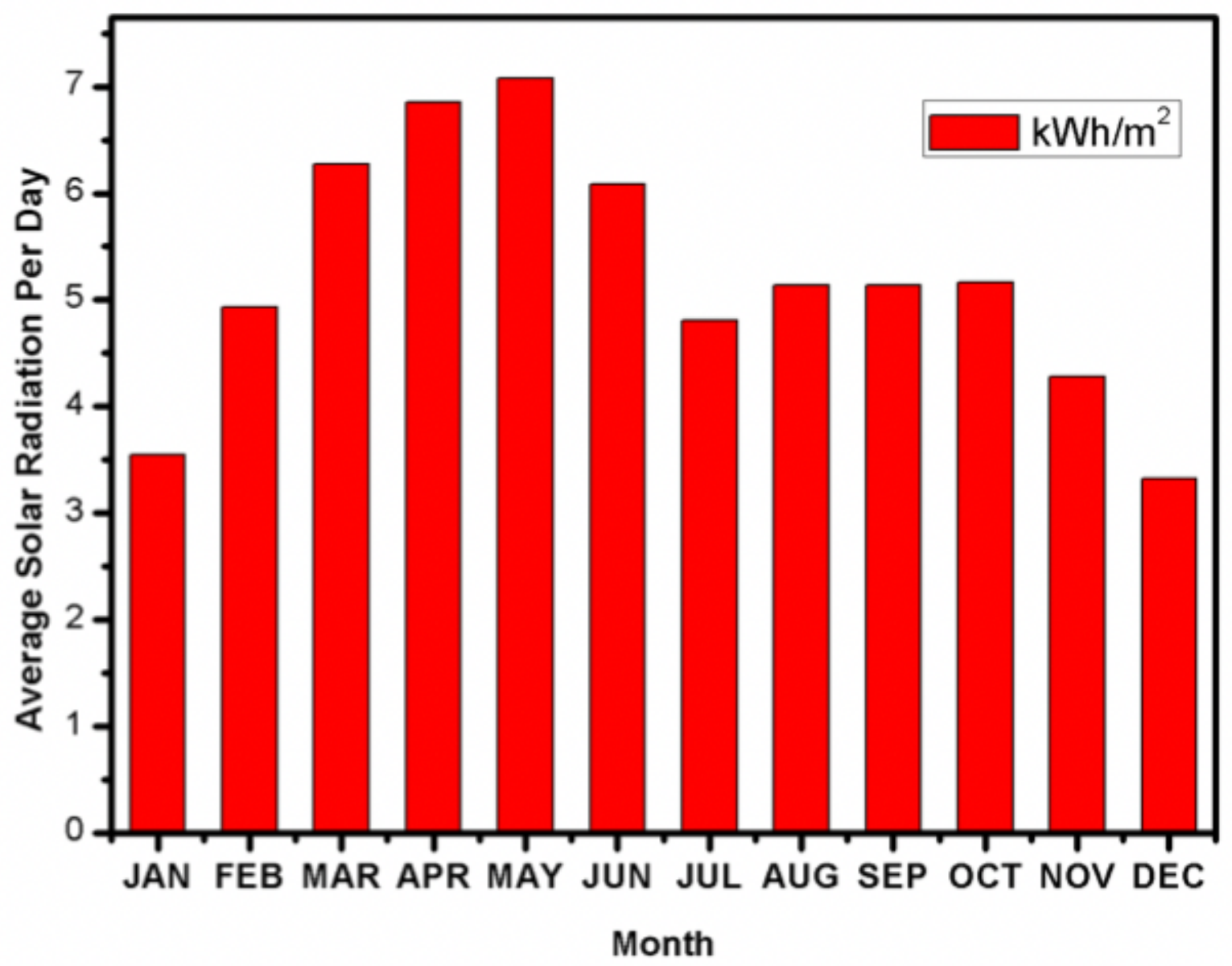

Figure 5

Average solar radiation per day in different month [Synergy Enviro] 


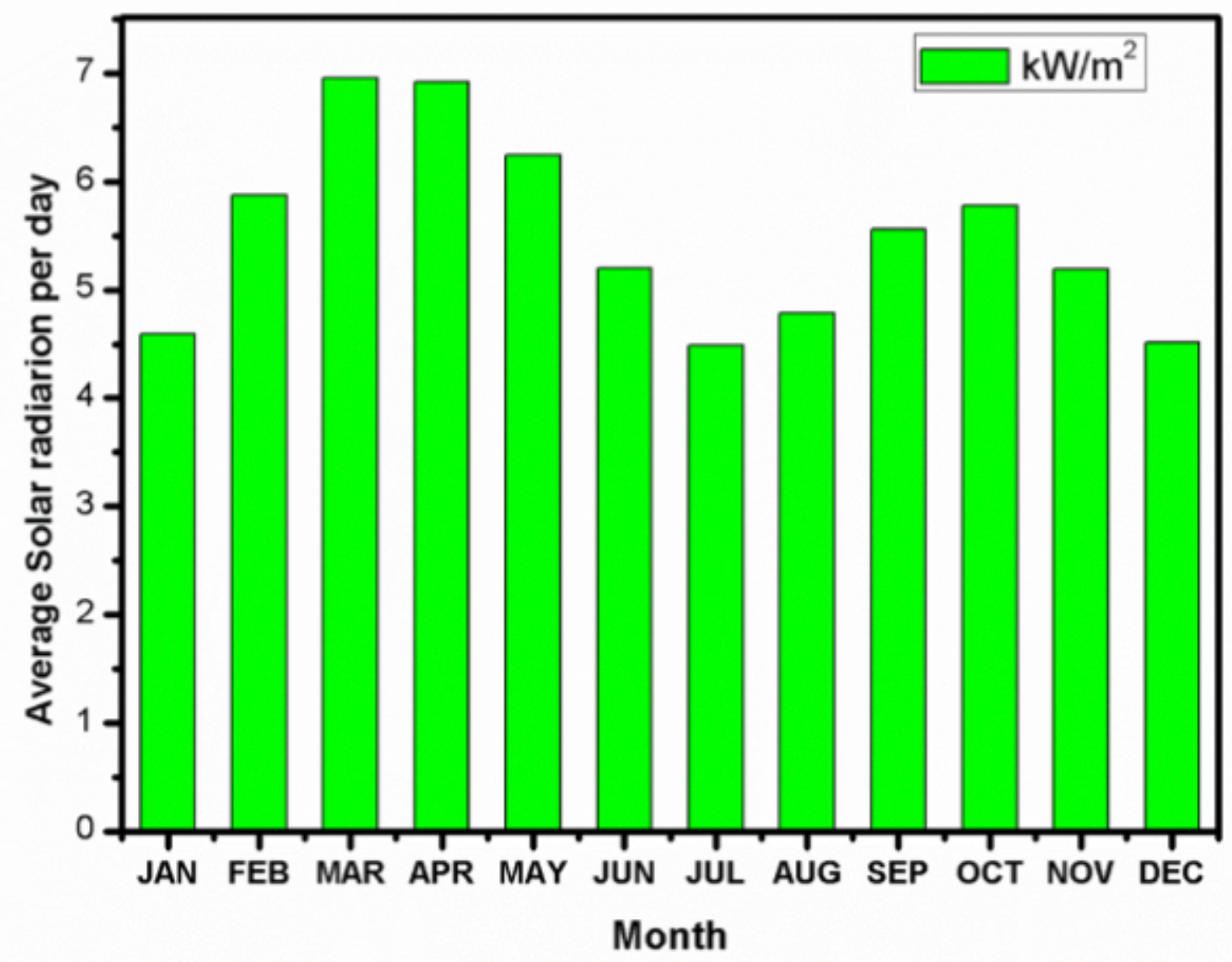

Figure 6

Average solar radiation per day in different month [pvwatts] 


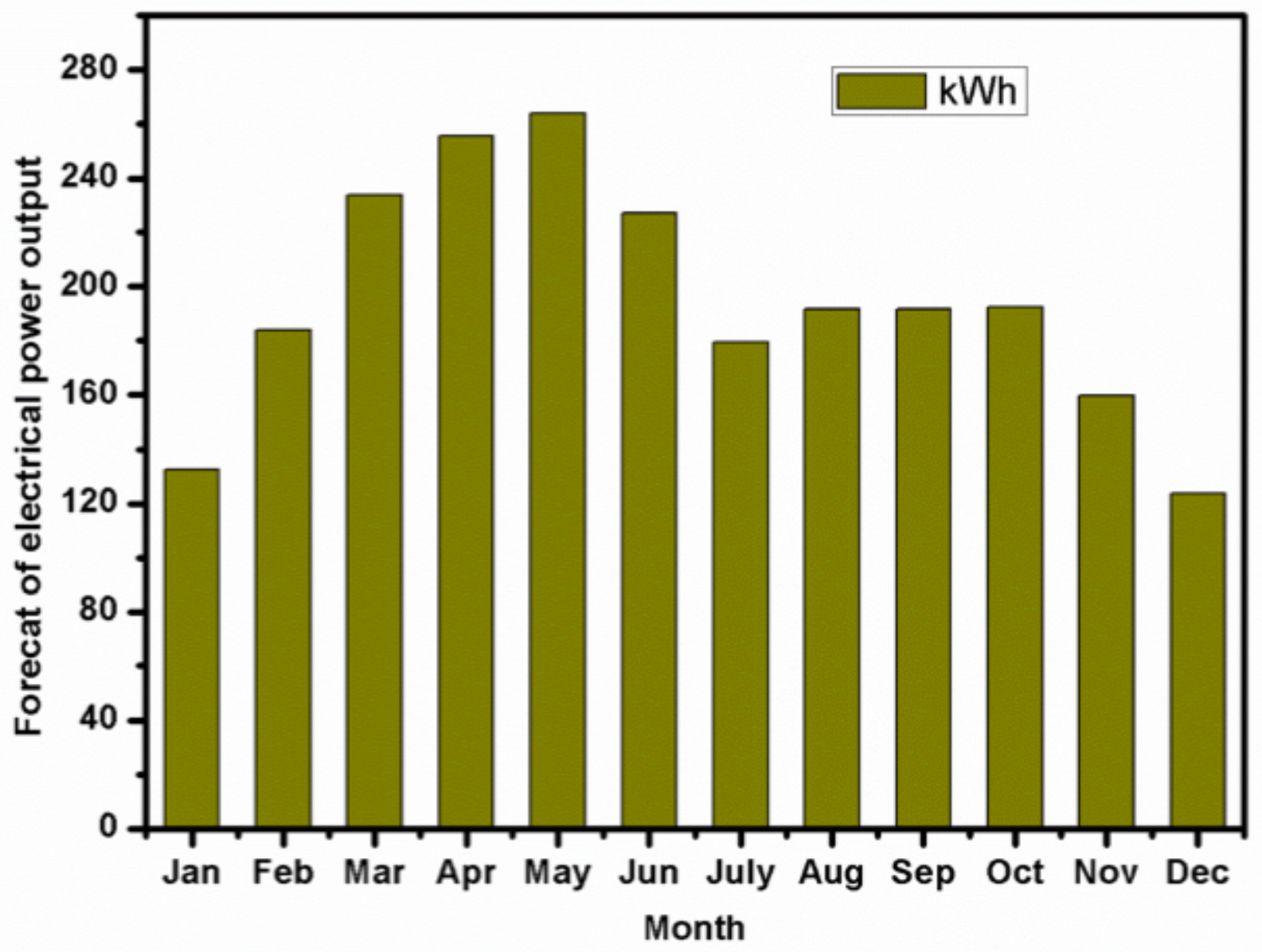

Figure 7

Forecasted production of electrical power in different month at installed location [Synergy Enviro] 


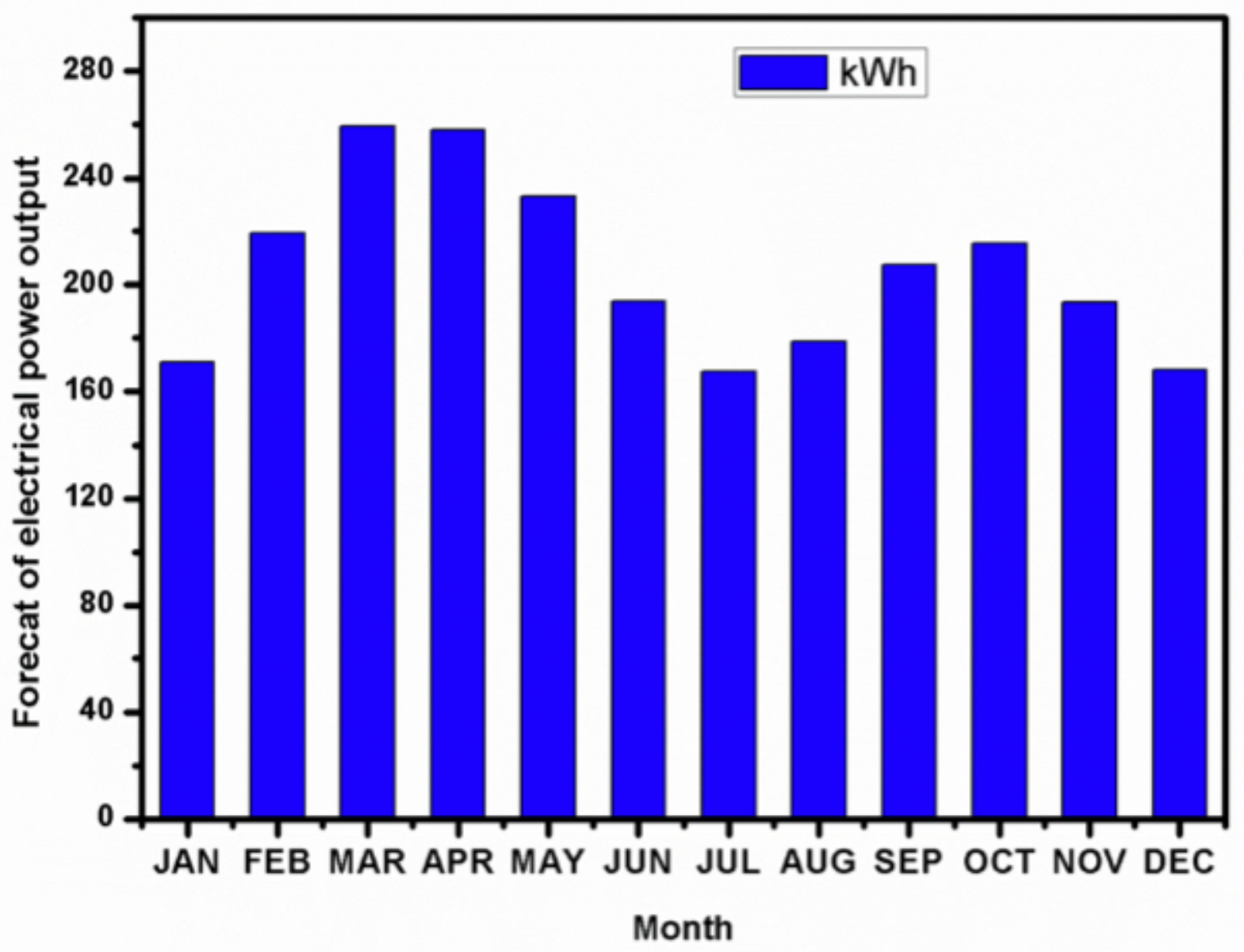

Figure 8

Forecasted production of electrical power in different month at installed location [PV watts] 


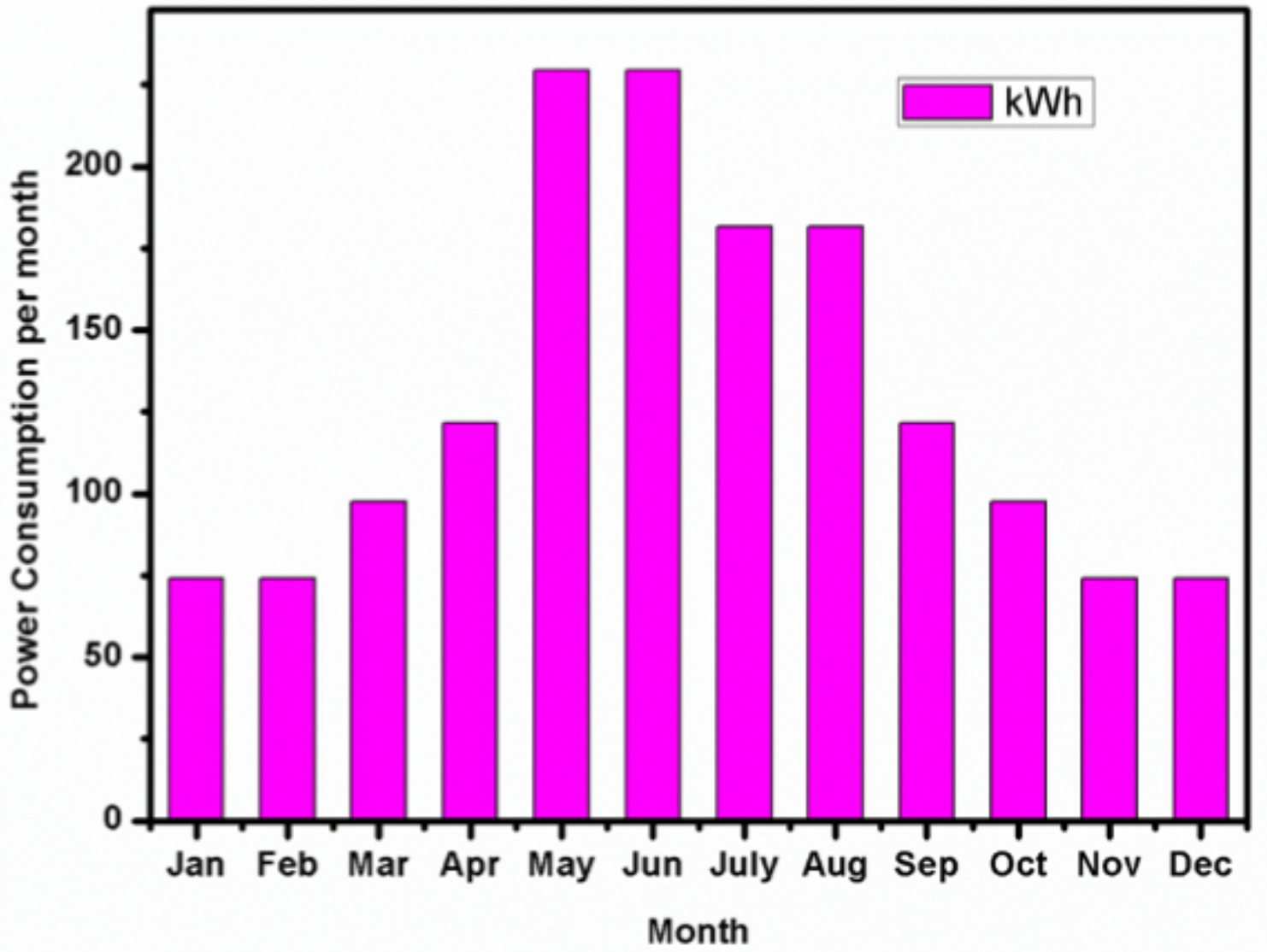

Figure 9

Monthly power consumption as per given load from PVT 


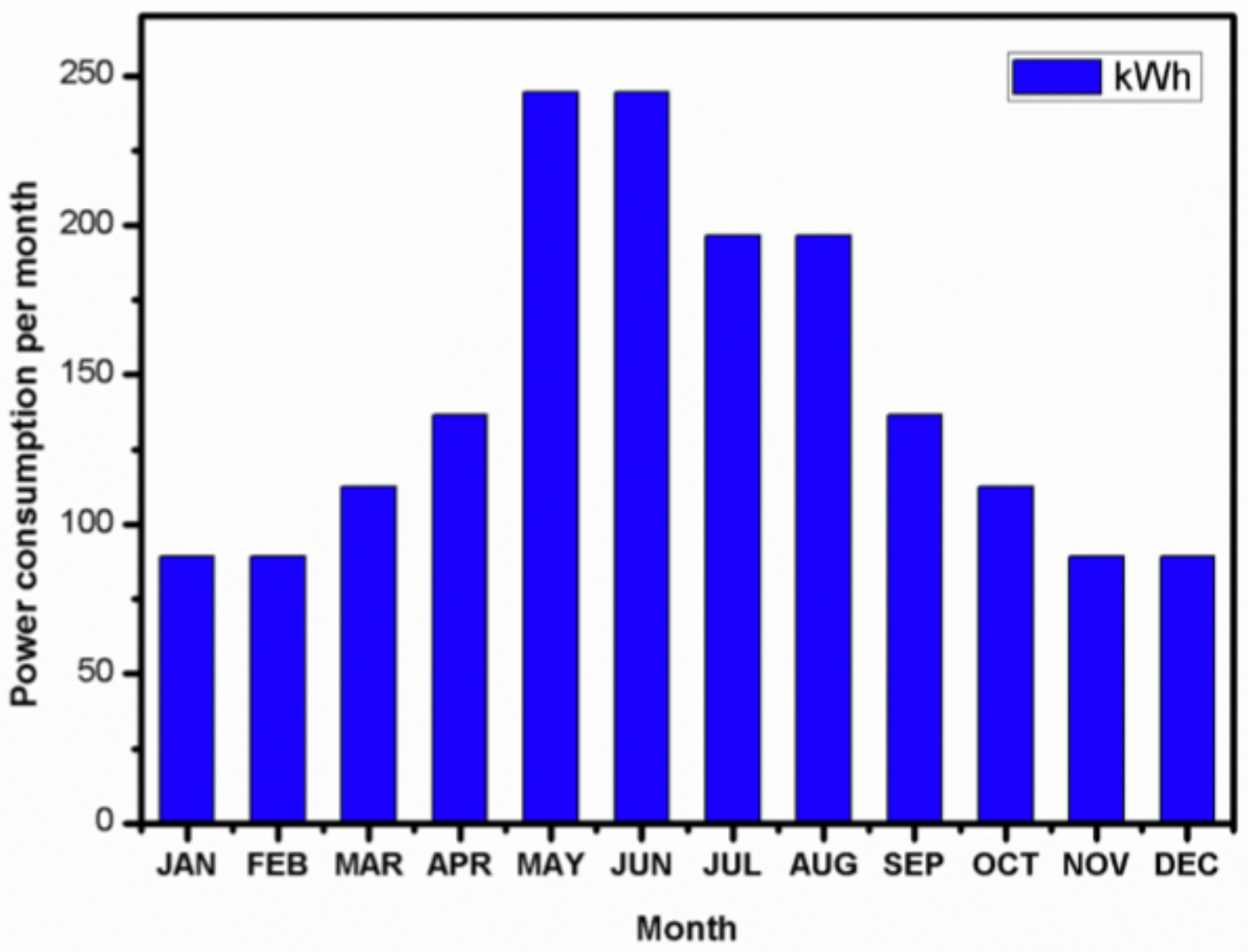

Figure 10

Average power consumption per month without PVT 


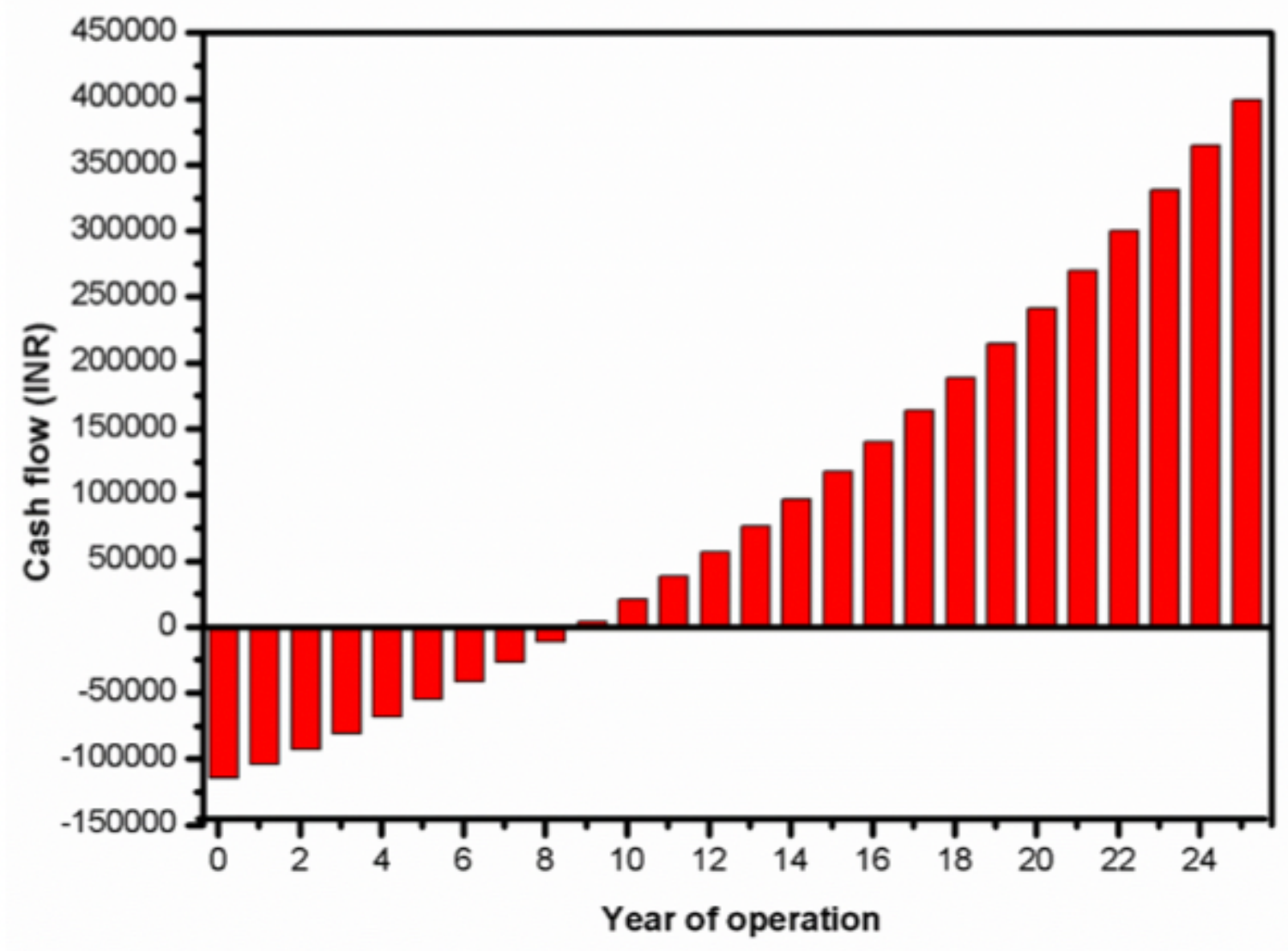

Figure 11

Cash flow and return on investment 